\title{
PENERAPAN STRATEGI PEMBELAJARAN METAKOGNITIF DALAM MENINGKATKAN PEMAHAMAN KONSEP MATEMATIKA
}

\author{
Halimah Soinbala ${ }^{1}$, Fauzi Mulyatna ${ }^{2}$ \\ Universitas Indraprasta PGRI ${ }^{1,2}$ \\ pos-el : soinbalahalimah@gmail.com ${ }^{1}$, fauzi.mulyatna@unindra.ac.id ${ }^{2}$
}

\begin{abstract}
ABSTRAK
Penelitian bertujuan mengetahui peningkatan kemampuan pemahaman konsep matematika siswa melalui strategi pembelajaran metakognitif, pada siswa kelas VIII SMP PLUS YAPIMDA. Metode penelitian yang digunakan adalah metode quasi eksperimen. Rancangan penelitianny adalah Nonequivalent Control Group Design. Cara pengambilan sampel melalui teknik purposive sampling. Populasi target dalam penelitian ini adalah SMP PLUS YAPIMDA, sedangkan populasi terjangkau adalah SMP PLUS YAPIMDA tahun ajaran 2017/2018. Sampel dalam penelitian ini adalah siswa kelas $\mathrm{VIII}^{\mathrm{A}}$ dan kelas $\mathrm{VIII}^{\mathrm{C}}$ sebanyak 20 siswa. Analisa data menggunakan uji-t yang terlebih dahulu dihitung normalitas gain menggunakan Uji Lilliefors dan diuji homogenitasnya menggunakan Uji Fisher. Berdasarkan pengujian hipotesis, didapat $t_{\text {hitung }}=5,243$ dan $t_{\text {tabel }}=1,69$ pada taraf signifikansi $5 \%$ dengan derajat kebebasan $(\mathrm{dk}=19)$ yang artinya $t_{\text {hitung }}(5,243)>t_{\text {tabel }}(1,69)$, maka $H_{0}$ ditolak dan $H_{1}$ diterima. Dengan demikian, dapat disimpulkan bahwa strategi pembelajaran metakognitif dapat meningkatkan kemampuan pemahaman konsep matematika.
\end{abstract}

Kata kunci : metakognitif, pemahaman, konsep, matematika

\section{ABSTRACT}

The research aims to know the capacity of understanding the mathematical concepts of students through metacognition, learning strategies on grade VIII of SMP PLUS YAPIMDA. The research method used was quasi experiment method. The design of penelitianny is the Nonequivalent Control Group Design. Way of sampling through purposive sampling technique. The target population in this research is the SMP PLUS YAPIMDA, whereas the population affordable is SMP PLUS YAPIMDA school year 2017/2018. The sample in this research are learners class VIII ${ }^{A}$ and $V_{I I I}{ }^{C}$ class and as many as 20 learners. Data analysis using the test- $t$ first calculated the gain using a normality test and Lilliefors test for homogent tested using Fisher. Based on hypothesis testing, obtained thitung $=5.243$ and $t_{\text {tabel }}=1.69$ at $5 \%$ significance level with the degrees of freedom $(d k=19)$ which means $t_{\text {hitung }}(5.243)>t_{\text {tabel }}(1.69)$, then $H_{0}$ was rejected and $H_{1}$ accepted. Thus, it can be concluded that learning strategies can improve comprehension Metacognition of mathematical concepts.

Keywords : metacognition,understanding, concept, mathematics

\section{PENDAHULUAN}

Majunya suatu bangsa dipengaruhi oleh mutu pendidikan dari bangsa itu sendiri, karena pendidikan yang berkualitas dapat menghasilkan tenaga-tenaga profesional atau sumber daya manusia (SDM) yang berkualitas pula. Melalui pendidikan, diharapkan dapat membentuk karakter manusia yang memiliki kemampuan akademis dan keterampilan lainnya, agar mampu mengembangkan potensi yang 
dimilikinya untuk memajukan bangsa Indonesia ini (Nurafiah, Nurlaelah, dan Sispiyati, 2013). Dalam Undangundang Nomor 20 Tahun 2003 tentang Sistem Pendidikan Nasional dicantumkan bahwa: "Tujuan pendidikan nasional adalah untuk berkembangnya potensi siswa agar menjadi manusia yang beriman dan bertakwa kepada Tuhan Yang Maha Esa, berakhlak mulia, sehat, berilmu, cakap, kreatif, mandiri dan menjadi warga negara yang demokratis serta bertanggung jawab". Salah satu contoh yang bertolak belakang dengan tujuan pendidikan adalah tingkat kecakapan, kreatifitas, dan kemandirian. Masih banyak siswa yang selalu menggantungkan sumber pengetahuan hanya kepada guru semata, banyak siswa yang bersifat pasif saat kegiatan belajar mengajar berlangsung.

Dalam lingkup pendidikan sekolah, siswa harus mempelajari banyak mata pelajaran, mata pelajaran matematika merupakan salah satu mata pelajaran wajib bagi siswa pada jenjang pendidikan dasar dan menengah (Nurmalasari, Winarso dan Nurhayati, 2015). Matematika merupakan salah satu bidang studi yang menduduki peranan penting dalam dunia pendidikan karena matematika merupakan ilmu pengetahuan yang harus dimiliki oleh siswa selain sebagai ilmu pengatahuan dasar juga sebagai saran berpikir ilmiah yang sangat diperlukan siswa dalam mengembangkan cara berpikir mereka setelah terjun ke masyarakat serta untuk keberhasilan belajar siswa dalam menempuh pendidikan yang lebih tinggi Sugiartini dkk (2013). Namun proses pembelajaran matematika yang dilaksanakan pada saat ini belum memenuhi harapan karena kemampuan pemahaman siswa masih rendah sehingga prestasi belajar siswa belum sesuai dengan apa yang diharapkan (Riyah dan Seruni, 2015).

Menurut Sanjaya (2006:36) "pemahaman konsep adalah kemampuan siswa yang berupa penguasaan sejumlah materi pelajaran". Siswa tidak hanya mengingat beberapa konsep saja, tetapi mampu menjelaskan kembali dalam pola lain dan menerapkannya pada konsep yang sesuai dengan struktur kognitif dari siswa itu sendiri. Dapat disimpulkan bahwa setelah diadakan pembelajaran matematika diharapkan siswa mampu mengaplikasikan konsep atau algoritma dalam pemecahan masalah.

Tujuan diberikannya pembelajaran matematika di sekolah dari jenjang pendidikan dasar sampai menengah Memahami konsep matematika, menjelaskan keterkaitan antar konsep dan mengaplikasikan konsep atau algoritma secara luwes, akurat, efisien dan tepat dalam pemecahan masalah; 2 . Menggunakan penalaran pada pola dan sifat, melakukan manipulasi matematika dalam membuat generalisasi dan menyusun bukti; 3. Menjelaskan gagasan dan pernyataan matematika; 4) pemecahan masalah yang meliputi kemampuan memahami masalah, merancang model matematika, menyelesaikan model, serta menafsirkan solusi yang diperoleh; 4 . Mengkomunikasikan gagasan dengan simbol, tabel, diagram, atau media lain untuk memperjelas keadaan atau masalah; 5. Memiliki sikap menghargai kegunaan matematika dalam kehidupan, yaitu memiliki rasa ingin 
tahu,perhatian, dan minat dalam mempelajari matematika, serta sikap ulet dan percaya diri dalam pemecahan masalah. Berdasarkan hal tersebut, tentu dapat kita rasakan bahwa fakta di lingkungan pendidikan sangat bersinggungan. Peserta didik yang kita kenal saat ini justru hanya menghafal rumus tanpa memahami konsep dasar sehingga cepat berputus asa ketika dihadapkan dengan soal yang lebih sulit.

Kemampuan pemahaman konsep dasar matematika siswa di sekolah sangat diperlukan agar pembelajaran matematika dapat bermakna yang dapat membuat siswa memiliki sikap menghargai kegunaan matematika dalam kehidupan, yaitu memiliki rasa ingin tahu,perhatian, dan minat dalam mempelajari matematika, serta sikap ulet dan percaya diri dalam pemecahan masalah. Mengingat kemampuan pemahaman konsep matematika sangat penting dalam membantu siswa untuk berpikir secara luwes sehingga beberapa lembaga melakukan survei untuk mengetahui capaian ketrampilan berpikir. Salah satunya yaitu survei yang dilakukan PISA pada tahun 2015. Dari hasil tes dan evaluasi yang dilakukan performa siswa Indonesia masih tergolong rendah. Berturut-turut rata-rata skor pencapaian siswa-siswi Indonesia untuk sains, membaca, dan matematika berada diperingkat 62, 61, dan 63 dari 69 negara yang dievaluasi. Peringkat dan rata-rata skor Indonesia tersebut tidak berbeda jauh dengan hasil tes dan survey PISA terdahulu pada tahun 2012 yang juga berada pada kelompok penguasaan materi yang rendah (Abdullah dan Iswandi, 2015).
Banyak faktor yang menyebabkan pemahaman konsep siswa rendah salah satunya menurut penelitian yang dilakukan Ratih, Sunardi, dan Dafik (2013) mengemukakan bahwa dalam mendapatkan konsep, struktur dan prinsip pada suatu materi umumnya siswa hanya mendengarkan penjelasan guru tanpa mempraktikkan sendiri dan Aktivitas guru dalam proses pembelajaran, sebagian besar guru menjelaskan materi dan langsung memberikan latihan-latihan soal serta model pembelajaran yang sering dilakukan guru masih belum berkembang serta kondisi pembelajaran yang masih bersifat konvensional dan tidak menyentuh ranah dimensi siswa itu sendiri, yaitu bagaimana sebenarnya belajar itu (belajar untuk belajar).

Untuk mengantisipasi masalah pendidikan tersebut, maka perlu dicarikan suatu alternatif metode dan strategi pembelajaran yang tepat guna sehingga dapat meningkatkan kemampuan pemahaman konsep siswa. Para guru hendaknya terus berusaha menyusun dan menerapkan berbagai cara yang bervariasi agar siswa tertarik dan bersemangat dalam mengikuti pelajaran matematika. Oleh karena itu harus dikembangkan strategi pembelajaran yang tidak hanya sekedar meningkatkan pengetahuan saja untuk siswa tetapi juga untuk membantu siswa menganalisis dan mengevaluasi langkah-langkah pengerjaan dalam mencari solusi yang benar dari permasalahan yang dihadapi. Salah satu cara untuk mengatasinya adalah pemilihan strategi pembelajaran dengan memperhatikan kondisi pembelajaran sehingga mampu meningkatkan kemampuan pemahaman konsep siswa. 
Ada berbagai model dan strategi pembelajaran yang dapat diterapkan dalam pembelajaran matematika salah satunya adalah strategi pembelajaran metakognitif. Strategi pembelajaran ini yang digunakan penulis dalam melakukan eksperimen. Strategi pembelajaran ini diharapkan mampu meningkatkan kemampuan pemahaman konsep matematika siswa, karena startegi pembelajaran ini lebih menekankan pada pengembangan kesadaran siswa akan kemampuan dirinya tentang pemahaman konsep, pemahaman masalah, mengembangkan hubungan pengetahun baru dengan yang lalu, strategi penyelesaian, refleksi proses dan solusi yang mengajarkan. strategi metakognitif merujuk kepada cara untuk meningkatkan kesadaran mengenai proses berpikir dan pembelajaran yang berlaku.

Menurut Kramarski dan Zoldan (2008) menyatakan bahwa strategi metakognitif merupakan pembelajaran yang menanamkan kesadaran bagaimana merancang, memonitor, serta mengontrol tentang apa yang mereka ketahui; apa yang diperlukan untuk mengerjakan; menitik beratkan pada aktivitas belajar; membantu dan membimbing siswa ketika mengalami kesulitan; serta membantu siswa dalam mengembangkan konsep diri mereka ketika sedang belajar matematika. Keunggulannya strategi metakognitif yaitu:

1. Meningkatkan kemampuan berpikir kritis siswa

2. Sangat membantu siswa dalam memahami konsep dari materi yang sedang mereka pelajari
3. Membuat siswa menjadi lebih aktif selama proses pembelajaran berlangsung

4. Pembelajaran matematika dengan pendekatan metakognitif dapat meningkatkan kepercayaan diri siswa dalam belajar matematika.

Dari latar belakang yang telah dikemukakan, penulis berasumsi bahwa strategi pembelajaran metakognitif mampu meningkatkan kemampuan pemahaman konsep siswa. Untuk membuktikan hal tersebut maka penulis akan melakukan penelitian dengan menggunakan strategi pembelajaran metakognitif. Atas dasar tersebut maka penulis mengangkat sebuah judul penelitian yaitu "Penerapan Strategi metakognitif dalam meningkatkan pemahaman konsep matematika siswa".

\section{METODE PENELITIAN}

Penelitian ini dilaksanakan di SMP PLUS YAPIMDA yang beralamat Jalan H. Naseh No 54, RT: 7/Rw:7. Kel. Lenteng Agung. Kec. Jagakarsa. Kab: kota Jakarta Selatan. Povinsi: DKI Jalarta. Kode Pos: 12610. Waktu penelitian adalah semester genap tahun ajaran 2017/2018 pada pertengahan April hingga awal Mei 2018. Penelitian ini berlangsung selama kurang lebih tiga bulan. Pada penelitian ini digunakan metode eksperimen dengan jenis penelitian kuantitatif, yaitu metode penelitian metode quasi eksperimen atau eksperimen semu. Rancangan penelitian yang digunakan dalam penelitian ini adalah Nonequivalent Control Group Design dengan pendekatan pre-test post-test. Menurut Sugiyono (2010:23) dalam desain ini, observasi dilakukan sebanyak dua kali, observasi dilakukan sebelum 
eksperimen yang disebut pre-test dan observasi dilakukan sesudah eksperimen atau biasa disebut post-test. Desain ini dapat digambarkan sebagai berikut:

\begin{tabular}{|l|l|l|l|}
\hline Kelompok & $\begin{array}{l}\text { Pre- } \\
\text { test }\end{array}$ & Perlakuan & $\begin{array}{l}\text { Post- } \\
\text { test }\end{array}$ \\
\hline $\begin{array}{l}\text { Kel. } \\
\text { Eksperimen } \\
(\mathrm{E})\end{array}$ & $\mathrm{O}_{1}$ & $\mathrm{X}_{1}$ & $\mathrm{O}_{2}$ \\
\hline $\begin{array}{l}\text { Kel. } \\
\text { Kontrol (C) }\end{array}$ & $\mathrm{O}_{3}$ & $\mathrm{X}_{2}$ & $\mathrm{O}_{4}$ \\
\hline
\end{tabular}

Gambar 1. Desain Penelitian

Keterangan :

$\mathrm{O}_{1}=$ tes awal pada kelompok eksperimen (pretest)

$\mathrm{X}_{1}=$ Penerapan menggunakan strategi pembelajaran metakognitif

$\mathrm{O}_{2}=$ tes akhir pada kelompok eksperimen (posttest)

$\mathrm{O}_{3}=$ tes awal pada kelompok Kontrol (pretest)

$\mathrm{X}_{2}=$ Penerapan Strategi Pembelajaran langsung

$\mathrm{O}_{4}=$ tes akhir pada kelompok Kontrol (posttest)

Dalam penelitian ini, populasi terjangkau adalah SMP PLUS YAPIMDA tahun ajaran 2017/2018. Menurut Arikunto (2013: 173) populasi adalah keseluruhan subjek penelitian. Dalam penelitian ini, sampel diambil dari sebagian jumlah populasi terjangkau. Hal ini sesuai dengan pendapat Arikunto (2013: 174) sampel adalah sebagian atau wakil populasi yang diteliti. Adapun pengambilan sampel menggunakan teknik purposive sampling. Teknik ini purposive sampling dalam pengambilan sampelnya, peneliti berdasarkan nilai rata-rata kelas yang tidak jauh berbeda diantara kedua kelas ini.

Dalam pengumpulan data, peneliti menggunakan instrumen bentuk esay sebanyak 5 butir soal. Pengumpulan data dilakukan sebanyak dua kali yaitu data yang diperoleh dari tes awal (pretest) dan data yang diperoleh dari tes akhir (posttest). Selanjutnya, dihitung perbandingan nilai dari pretest dan posttest untuk mengetahui peningkatan kemampuan pemahaman konsep matematika dan membandingkan pemahaman konsep matematika kelas kontrol dan kelas eksperimen. Setelah data didapat, data diolah normalitasnya menggunakan Uji Lilliefors dan kemudian di uji homogenitasnya mengguanakan Uji Fisher. Setelah data dinyatakan berdistribusi normal dan homogen, selanjutnya data dianalisis menggunakan uji-t sehingga dapat diketahui peningkatan kemampuan pemahaman konsep matematika melalui strategi pembelajaran metakgnitif.

\section{HASIL DAN PEMBAHASAN}

Secara deskriptif, data hasil penelitian diperoleh dari hasil tes kemampuan pemahaman konsep matematika sebanyak 5 butir soal essay dengan jumlah sampel adalah 20 siswa kelas VIII ${ }^{\mathrm{A}}$ dan kelas VIII ${ }^{\mathrm{C}}$ SMP PLUS YAPIMDA pada tahun ajaran 2017/2018. Dari data tersebut, kemudian dihitung mean, median, modus, varian, dan simpangan baku serta nilai maksimum dan minimumnya. Adapun ringkasan hasil peritungan dapat dilihat pada Tabel 1 dan Tabel 2, dan simpangan baku serta nilai maksimum dan minimumnya. 
Tabel 1. Ringkasan Kemampuan Pemahaman Konsep Matematika Siswa Eksperimen Sebelum Perlakuan (Pretest) dan Sesudah Perlakuan (Posttest)

\begin{tabular}{|c|c|c|}
\hline Statistik & Pretest & Posttest \\
\hline Nilai Min & 38 & 58 \\
\hline Nilai Maks & 61 & 80 \\
\hline Mean & 44,9 & 66,5 \\
\hline Median & 41,928 & 65,5 \\
\hline Modus & 42,5 & 64,167 \\
\hline Set Def & 6,198 & 5,785 \\
\hline Varians & 38,421 & 33,473 \\
\hline
\end{tabular}

Tabel 2. Ringkasan Kemampuan Pemahaman Konsep Matematika Siswa Kontrol Sebelum Perlakuan (Pretest) dan Sesudah Perlakuan (Posttest)

\begin{tabular}{|c|c|c|}
\hline Statistik & Pretest & Posttest \\
\hline Nilai Min & 31 & 46 \\
\hline Nilai Maks & 60 & 71 \\
\hline Mean & 42 & 55,75 \\
\hline Median & 41,928 & 53,83 \\
\hline Modus & 42,5 & 52,583 \\
\hline Set Def & 6,198 & 6,972 \\
\hline Varians & 38,421 & 48,618 \\
\hline
\end{tabular}

Berdasarkan Tabel 1 dan Tabel 2, dapat dilihat bahwa nilai terendah pada pretest kelas eksperimen adalah 38 dan nilai terendah pada posttest kelas eksperimen adalah 58. Nilai tertinggi pada pretest kelas eksperimen adalah 61 dan nilai tertinggi pada post-test kelas eksperimen adalah 80. Sedangkan nilai terendah pada pretest kelas kontrol adalah 31 dan nilai terendah pada posttest kelas kontrol adalah 46. Nilai tertinggi pada pretest kelas kontrol adalah 60 dan nilai tertinggi pada posttest kelas kontrol adalah 71. Secara visual, statistik nilai kelas eksperimen lebih tinggi dari pada statistik nilai kelas kontrol. Dengan demikian, dapat disimpulkan bahwa strategi pembelajaran metakognitif dapat meningkatkan kemampuan pemahaman konsep matematika.
Selanjutnya dilakukan uji normalias data. Dalam penelitian ini, peneliti melakukan uji normalitas data menggunakan Uji Lilliefors dengan sampel sebanyak 20 siswa dengan taraf signifikan $\alpha=0,05$. Berikut disajikan tabel uji normalitas kemampuan pemahaman konsep matematika siswa menggunakan Uji Lilliefors:

Tabel 3. Hasil Uji Normalitas Kemampuan

Pemahaman Konsep Matematika Kelas

Eksperimen dan Kontrol serta $N$-gain

\begin{tabular}{|c|c|c|c|}
\hline Jenis Tes & $\mathrm{L}_{\text {hitung }}$ & $\mathrm{L}_{\text {tabel }}$ & Simpulan \\
\hline $\begin{array}{c}\text { Pretest } \\
\text { Eksperimen }\end{array}$ & 0,160 & 0,190 & Normal \\
\hline $\begin{array}{c}\text { Posttest } \\
\text { Eksperimen }\end{array}$ & 0,158 & 0,190 & Normal \\
\hline $\begin{array}{c}\text { Pretest } \\
\text { Kontrol }\end{array}$ & 0,167 & 0,190 & Normal \\
\hline $\begin{array}{c}\text { Posttest } \\
\text { Kontrol }\end{array}$ & 0,183 & 0,190 & Normal \\
\hline $\begin{array}{c}\text { Gain } \\
\text { Eksperimen }\end{array}$ & 0,098 & 0,190 & Normal \\
\hline $\begin{array}{c}\text { Gain } \\
\text { Kontrol }\end{array}$ & 0,148 & 0,190 & Normal \\
\hline
\end{tabular}

Dari Tabel 3 dapat dilihat bahwa data pretest, posttest, dan data n-gain pada $\quad L_{\text {hitung }}<L_{\text {tabel }}$ pada taraf signifikansi 5\% atau $\alpha=0,05$ dengan jumlah sampel sebanyak 20 siswa sehingga disimpulkan bahwa $H_{0}$ diterima dan $H_{l}$ ditolak yang artinya data berdistribusi normal. Setelah dilakukan uji normalitas, selanjutmya dilakukan uji homogenitas. Uji homogenitas ini dilakukan untuk mengetahui apakah varian dari kedua populasi homogen. Dalam penelitian ini, rumus yang digunakan untuk melakukan uji homogenitas adalah Uji Fisher. Berikut disajikan tabel hasil perhitungan uji homogenitas menggunakan Uji Fisher: 
Tabel 4. Hasil Perhitungan Uji Homogenitas Menggunakan Uji Fisher

\begin{tabular}{|c|c|c|c|c|}
\hline Tes & Varian & $\mathbf{F}_{\text {hit. }}$ & $\mathbf{F}_{\text {tab. }}$ & simpulan \\
\hline Pre- & & & & \\
\cline { 5 - 5 } test & 38,09 & 1,32 & 2,18 & Homogen \\
\cline { 2 - 2 } $\begin{array}{c}\text { Post } \\
\text {-test }\end{array}$ & 33,47 & 1,452 & 2,18 & Homogen \\
\cline { 2 - 2 } $\begin{array}{c}\text { N- } \\
\text { gain }\end{array}$ & 0,005 & 1,20 & 2,18 & Homogen \\
\cline { 2 - 2 } \cline { 5 - 5 } & 0,007 & & & \\
\hline
\end{tabular}

Dari peritungan yang telah dilakukan, diperoleh varian data pretest kelas eksperimen sebesar 29,09 dan kelas kontrol sebesar 38,42. Tabel distribusi $\mathrm{F}$ untuk $\alpha=0,05$ dengan $\mathrm{dk}$ pembilang $=19$ dan $\mathrm{dk}$ penyebut $=19$ diperoleh $F_{\text {hitung }}=1,32 ; \mathrm{F} 0,05(19,19)=$ 2,18. Berdasarkan kriteria pengujian, diperoleh $F_{\text {hitung }}=1,32<F_{\text {tabel }}=2,18$. Sehingga dapat disimpulkan bahwa $H_{0}$ diterima yang artinya sampel dari kedua data adalah homogen.

Varian data posttest kelas eksperimen sebesar 33,47 dan kontrol sebesar 48,61. Tabel distribusi $\mathrm{F}$ untuk $\alpha=0,05$ dengan $\mathrm{dk}$ pembilang $=19 \mathrm{dan}$ dk penyebut $=19$ diperoleh Fhitung $=$ 1,$27 ; \quad F \quad 0,05 \quad(19,19)=2,18$. Berdasarkan kriteria pengujian, diperoleh $F_{\text {hitung }}=1,452<F_{\text {tabel }}=2,18$. Sehingga dapat disimpulkan bahwa $H_{0}$ diterima yang artinya sampel dari kedua data adalah homogen.

Data n-gain kelas eksperimen sebesar 0,005 dan kontrol sebesar 0,007 . Tabel distribusi F untuk $\alpha=0,05$ dengan $\mathrm{dk}$ pembilang $=19 \mathrm{dan} \mathrm{dk}$ penyebut $=19$ diperoleh $F_{\text {hitung }}=1,20$; $F \quad 0,05(19,19)=2,18$. Berdasarkan kriteria pengujian, diperoleh $F_{\text {hitung }}=$ 1,20 dan $F_{\text {tabel }}=2,18\left(F_{\text {hitung }}=1,20<\right.$ $\left.F_{\text {tabel }}=2,18\right)$. Sehingga dapat disimpulkan bahwa $H_{0}$ diterima yang artinya sampel dari kedua data adalah homogen.

Setelah uji normalitas dan uji homogenitas, selanjutnya adalah uji hipotesis penelitian. Untuk melakukan uji hipotesis, peneliti menggunakan uji-t dengan hipotesis sebagai berikut:

$\mathrm{H}_{0}: \mu_{A}<\mu_{B}$

$\mathrm{H}_{1}: \mu_{A}>\mu_{B}$

$H_{0}$ : tidak terdapat perbedaan pemahaman konsep matematika antara kelompok eksperimen dan kelompok kontrol.

$H_{1}$ : terdapat perbedaan tentang pemahaman konsep matematika antara kelompok eksperimen dan kelompok kontrol.

Keterangan:

$\mu_{A} \quad=$ rerata data setelah treatment.

$\mu_{B} \quad=$ rerata data sebelum treatment.

Adapun kriteria pengujian yaitu:

Terima $\mathrm{H}_{0}$, jika $\mathrm{t}_{\text {hitung }}<\mathrm{t}_{\text {tabel }}$ dan

Tolak $\mathrm{H}_{0}$, jika $\mathrm{t}_{\text {hitung }}>\mathrm{t}_{\text {tabel }}$

Tabel 5. Hasil Uji Hipotesis

\begin{tabular}{|c|c|c|c|}
\hline Test & $\mathrm{dk}$ & $\mathrm{T}_{\text {hitung }}$ & $\mathrm{T}_{\text {tabel }}$ \\
\hline Pretest & 38 & 1,578 & 1,69 \\
\hline Posttest & 38 & 5,306 & 1,69 \\
\hline n-gain & 38 & 5,243 & 1,69 \\
\hline
\end{tabular}

Dari Tabel 5 dapat dilihat bahwa $t_{\text {hitung }}$ pretest $=1,578<$ tabel $=1,69$, dengan demikian $H_{0}$ diterima pada taraf signifikan $\alpha=0,05$. Hal ini dapat disimpulkan bahwa tidak terdapat perbedaan pemahaman konsep matematika siswa kelas kontrol dan kelas eksperimen. Sedangkan $t_{\text {hitung }}$ posttest $=5,306>\mathrm{t}_{\text {tabel }}=1,69$, dengan demikian $\mathrm{H}_{0}$ ditolak pada taraf signifikan $\quad \alpha=0,05$ dan dapat 
disimpulkan bahwa terdapat perbedaan yang signifikan pemahaman konsep matematika kelas kontrol dan kelas eksperimen melalui strategi pembelajaran metakognitif. Selain itu juga dapat dilihat peningkatan pemahaman siswa kelas eksperimen yang menerapakan strategi pembelajaran metakognitif dengan kelas kontrol yang menerapkan pembelajaran konvensional atau $\mathrm{N}$ gainnya sebesar 5,243.

Berdasarkan hasil analisis yang dilakukan pada nilai Pre-test dan Posttest diperoleh nilai siswa post-test atau nilai pemahaman konsep matematika sesudah perlakuan menggunakan strategi pembelajaran metakognitif memiliki rata-rata, median, modus, dan simpangan baku lebih tinggi dari pada nilai pre-test atau nilai kemampuan pemahaman konsep matematika siswa sebelum menggunakan menggunakan strategi pembelajaran metakognitif. Hal ini juga berarti terdapat peningkatan kemampuan kemanpuan pemahaman konsep matematika siswa di SMP Plus YAPIMDA pada materi bangun ruang dengan penerapan strategi pembelajaran metakognitif.

Sebelum diberikan perlakuan dengan penerapan strategi pembelajaran metakognitif, siswa kelas kontrol dan kelas eksperimen diberikan pre-test kemampuan pemahaman konsep matematika. Dalam proses mengerjakan pre-test, perserta didik awalnya mengalami kesulitan karena pengerjaan soal menuntut siswa untuk mampu menghubungkan pemahaman konsep awal tentang bangun datar. Setelah nilai dari pretest didapat, barulah siswa diberi perlakuan dengan penerapan strategi pembelajaran metakognitif untuk kelas eksperimen dan pembelajaran konvensional untuk kelas kontrol.

Pada awal pertemuan untuk kelas eksperimen, respon siswa terhadap penerapan strategi pembelajaran metakognitif tidak begitu positif, mereka terlihat kurang tertarik dan banyak pula siswa yang tidak paham atau mengalami kesulitan dalam mengikuti proses pembelajaran. Hal ini terjadi karena siswa belum terbiasa dengan pembelajaran yang menuntut siswa menghubungan pengetahuann awal dengan materi, memantau dan mengevaluasi tentang pemahamannya sendiri. Pembelajaran sebelumnnya hanya terpusat pada guru dan siswa hanya diberikan latihan-latihan soal yang menyelesaikan sama seperti contoh yang telah guru berikan.

Selain itu, banyak siswa yang tidak menguasai materi bangun ruang yang sebenarnya telah diajarkan pada pembelajaran sebelumnya yang menerapkan model pembelajaran konvensional. Sehingga pada pertemuan awal peneliti memerlukan banyak waktu untuk membimbing siswa dalam menjawab pertanyaan-pertanyaan yang ada dalam contoh soal. Banyak siswa yang tidak paham dalam menjawab soal, mereka menjawab seadannya atau mereka tidak menjawab sama sekali. Sehingga dipertemuan akhir kegiatan mempresentasikan hasil kerja mereka untuk dibahas secara bersama sama kurang berjalan dengan baik. Ketika diminta mengumpulkan hasil kerja mereka, hanya beberapa orang yang mengumpulkan dan sebagian orang beralasan belum selesai mengerjakannya. 
Pada pertemuan pertama dan kedua, penerapan pembelajaran strategi pembelajaran metakognitif masih terdapat kendala dan belum sesuai harapan. Pada pertemuan selanjutnya siswa sudah mulai terbiasa dengan strategi pembelajaran metakognitif yang diterapkan. Siswa menjadi lebih aktif dan berkontribusi dalam menyampaikan ide-ide atau gagasan dan mencari informasi melalui berbagai sumber belajar dan mulai memantau mengontrol dan mengevaluasi pemahamannya. Setiap siswa mulai mengerjakan setiap tahapan strategi pembelajaran metakognitif.

Setelah, mendapatkan perlakuan strategi pembelajaran metakognitif, siswa diberikan tes kembali berupa post-test kemampuan pemahaman konsep matematika. Ketika siswa mulai mengerjakan post-test ini, siswa tidak terlalu mengalami kesulitan yang berarti karena siswa sudah memahami konsep bangun datar dan dihubungkan ke bangun ruang. Jawaban siswa lebih beragam dan meningkat menujukan siswa lebih memahami dari sebelumnya dalam menjawab tes kemampuan pemahaman konsep matematika siswa.

Penelitian ini juga didasarkan pada penelitian yang telah dilakukan sebelumnya, yaitu penelitian yang dilakukan oleh dilakukan Linda Rismayanti Nurmalasari, Widodo Winarso, Eti Nurhayati dengan judul "Pengaruh Kemampuan Metakognitif terhadap Hasil Belajar Matematika di SMP Negeri 2 Leuwimunding Kabupaten Majalengka". Penelitian yang dilakukan di SMP Negeri Leuwimunding Kabupaten Majalengka. Populasinya seluruh siswa kelas VIII di
SMP Negeri 2 Leuwimunding Kabupaten Majalengka. Menyimpulkan bahwa kemampuan metakognitif yang dimiliki siswa termasuk kedalam kategori cukup begitupun hasil belajar yang dimiliki termasuk kedalam kategori cukup. Sehingga semakin baik kemampuan metakognitif yang dimiliki siswa maka semakin baik juga hasil belajar yang diperoleh. Hasil dari uji hipotesis menunjukan bahwa terdapat pengaruh kemampuan metakognitif terhadap hasil belajar matematika. Dan Penelitian yang dilakukan Cut Nurmaliah dengan judul "Peranan Kemampuan Metakognitif Dalam Pemecahan Masalah Matematika Sekolah Dasar". Sampel diambil dari tiga sekolah dasar yang dipilih secara acak dari 44 sekolah dasar yang mengajarkan matematika dalam kelas kelas yang heterogen dan tanpa pengelompokkan ataupun pemisahan kemampuan. Sampel yang terpilih sebanyak 240 siswa yang berasal dari siswa kelas 5 sebanyak 6 kelas dari 3 sekolah (dua kelas setiap sekolahnya). Penelitian ini menyimpulkan bahwa kemampuan metakognitif mempunyai peranan yang sangat strategis untuk memecahkan masalah-masalah dalam pembelajaran matematika. Hasil penelitian menunjukkan selain dapat membuat siswa mencapai prestasi yang lebih baik dalam memecahkan masalah, kemampuan metakognitif juga berperan dalam interaksi antara kemampuan siswa dengan metode mengajar yang digunakan guru, dan ini mempunyai manfaat yang lebih jika diterapkan pada siswa dengan kemampuan rendah terutama di sekolah dasar. 


\section{KESIMPULAN}

Berdasarkan hasil penelitian dan pembahasan, maka dapat disimpulkan bahwa terdapat peningkatan melalui strategi pembelajaran metakognitif terhadap kemampuan kemampuan pemahaman konsep matematika. Hal tersebut dapat dilihat dari hasil penelitian pada materi bangun ruang, diperoleh nilai rata-rata pada pretest yang tidak menggunakan strategi pembelajaran metakognitif yaitu 55,75. Hal ini menunjukkan bahwa rata-rata nilai pretest lebih rendah dibandingkan dengan rata-rata nilai posttest yaitu 66,5. Setelah dilakukan uji hipotesis yaitu uji $t$, dengan nilai thitung $(5,036)>$ $t_{\text {tabel }}(1,69)$, maka hipotesisnya $\mathrm{H}_{1}$ diterima yaitu menunjukkan bahwa terdapat perbedaan antara (pretest) dan (posttest). Dari penelitian ini, dapat disimpulkan bahwa dalam pembelajaran Matematika sebaiknya dapat menggunakan atau memilih model pembelajaran yang sesuai dengan proses pembelajaran, sehingga dapat menciptakan suasana belajar yang menyenangkan. Diharapkan pula agar mampu menerapkan model atau strategi yang inovatif agar proses pembelajaran lebih aktif, kreatif dan menyenangkan sehingga siswa lebih bersemagat mengikuti pembelajaran. Sehingga pada hasil akhirnya, nilai siswa akan meningkat dari yang sebelumnya.

\section{DAFTAR PUSTAKA}

Abdullah dan Iswandi. (2015). Perancangan Sistem Pendaftaran Online Pasien Pada Klinik dengan Metode FIFO Berbasis Web Service. Jurnal Teknik Informatika. 6(1).
Arikunto, Suharsimi. (2013). Prosedur Penelitian: Suatu Pendekatan Praktik. Jakarta: Rineka Cipata Kramarski, B. \& Zoldan, S. (2008). Using Errors as Springboards For Enhancing Mathematical Reasoning with Three Metacognitive Approaches. The Journal of Educational Research, 102 (2), 137$1 \quad 5 \quad 1$ http://education.biu.ac.il/en/node/74 7 . Diakses: 12 Mei 2018, Pukul 18:20.

Nurafiah, F., E. Nurlaelah dan R. Sispiyati. (2013). Perbandingan Peningkatan Kemampuan Berpikir Kritis Siswa SMP antara yang Memperoleh Pembelajaran MeansEnds Analysis (MEA) dan Problem Based Learning (PBL). Jurnal Pendidikan Pengajaran MIPA. 18(1), 9-15.

Ratih, Sunardi, dan Dafik. (2013). Identifikasi Faktor Penyebab Rendahnya Penguasaan Materi dalam Ujian Nasional Matematika SMA Program IPA Tahun Ajaran 2009/2010 di Kabupaten Banyuwangi. Pancaran. 2(1), 185196.

Riyah dan Seruni. (2015). Peningkatan Kemampuan Pemahaman Siswa Pada Mata Pelajaran Matematika Menggunakan Model Project Based Learning. JKPM: Jurnal Kajian Pendidikan Matematika. 1(1), 7690.

Nurmalasari, L.R., Winarso, W., dan Nurhayati, E. (2015). Pengaruh Kemampuan Metakognisi terhadap Hasil Belajar Matematika di SMP Negeri 2 Leuwimunding Kabupaten Majalengka. Nusantara of Research. 02(02), 133-147.

Sanjaya, W. (2006). Strategi Pembelajaran Berorientasi Standar Proses Pendidikan. Jakarta: Kencana Prenada Media Group.

Sugiartini, dkk. (2013). Pengaruh model pembelajaran metakognitif terhadap 
kemampuan pemecahan masalah matematika siswa kelas V SD gugus depan III kecamatan tejakula. http://ejournal.undiksha.ac.id/index. php/JJPGSD/article/view/729.

Diunduh: 21 April 2018, Pukul 19:21.
Sugiyono. 2010. Metode Penelitian Pendidikan Pendekatan Kuantitatif, kualitatif, dan $R \& D$. Bandung: Alfabeta

Undang- undang Nomor 20 Tahun 2003 tentang Sistem Pendidikan Nasional 